NBER WORKING PAPER SERIES

\title{
WHAT SETS COLLEGE THRIVERS AND DIVERS APART? A CONTRAST IN STUDY HABITS, ATTITUDES, AND MENTAL HEALTH
}

\author{
Graham Beattie \\ Jean-William P. Laliberté \\ Catherine Michaud-Leclerc \\ Philip Oreopoulos \\ Working Paper 23588 \\ http://www.nber.org/papers/w23588
NATIONAL BUREAU OF ECONOMIC RESEARCH
1050 Massachusetts Avenue
Cambridge, MA 02138
July 2017

We are very grateful to Aloysius Siow, Nathalie Bau, Yosh Halberstam, Uros Petronijevic for helpful discussions. We also thank Aaron de Mello for web development and Matthew Hendrickson for helping us compile the administrative data. Financial support for this research was provided by the Ontario Human Capital Research and Innovation Fund. Any omissions or errors are our own responsibility. The views expressed herein are those of the authors and do not necessarily reflect the views of the National Bureau of Economic Research.

NBER working papers are circulated for discussion and comment purposes. They have not been peer-reviewed or been subject to the review by the NBER Board of Directors that accompanies official NBER publications.

(C) 2017 by Graham Beattie, Jean-William P. Laliberté, Catherine Michaud-Leclerc, and Philip Oreopoulos. All rights reserved. Short sections of text, not to exceed two paragraphs, may be quoted without explicit permission provided that full credit, including $(\odot)$ notice, is given to the source. 
What Sets College Thrivers and Divers Apart? A Contrast in Study Habits, Attitudes, and Mental Health

Graham Beattie, Jean-William P. Laliberté, Catherine Michaud-Leclerc, and Philip Oreopoulos NBER Working Paper No. 23588

July 2017

JEL No. I20,I23,I26,J20

\section{ABSTRACT}

Students from 4-year colleges often arrive having already done very well in high school, but by the end of first term, a wide dispersion of performance emerges, with an especially large lower tail. Students that do well in first year (we call the top 10 percent Thrivers) tend to continue to do well throughout the rest of their time in university. Students that do poorly (we call the bottom 10 percent Divers) greatly struggle and are at risk of not completing their degree. In this paper we use a mandatory survey with open ended questions asking students about their first-year experience. This allows us to explore more closely what sets Thrivers and Divers apart, in terms of study habits, attitudes, and personal experiences. We find that poor time management and lack of study hours are most associated with poor academic performance, and that those who struggle recognize these weaknesses. Divers also report feeling more depressed and unhappy with their lives. We posit an 'academic trap', whereby initial poor performance is related to poor time management which in turn lowers expectations, which in turn leads to lower study time, and so on. Thrivers, in contrast, study significantly more and meet with course instructors.

Graham Beattie

University of Pittsburgh

Department of Economics

4901 Wesley W. Posvar Hall

230 South Bouquet Street

Pittsburgh, PA 15260

grb57@pitt.edu

Jean-William P. Laliberté

Department of Economics

University of Toronto

150 St. George Street

Toronto, ON M5S 3G7

CANADA

jw.plaliberte@mail.utoronto.ca
Catherine Michaud-Leclerc

Department of Economics

University of Toronto

150 St. George Street

Toronto, ON M5S 3G7

Canada

c.michaudleclerc@mail.utoronto.ca

Philip Oreopoulos

Department of Economics

University of Toronto

150 St. George Street

Toronto, ON M5S 3G7

CANADA

and NBER

philip.oreopoulos@utoronto.ca

A online appendix is available at http://www.nber.org/data-appendix/w23588 


\section{Introduction}

With postsecondary enrollments having increased dramatically over the last several decades and the importance of degree completion continuing to be emphasized by policy makers and parents alike, more attention is being directed towards helping post-secondary students finish and exit with valuable experience and skills (Oreopoulos and Petronijevic, 2013). Despite efforts to increase student support, a large fraction of students still fail to graduate. In Canada, for example, a quarter of students registered in a four-year university program do not complete their degree within five years (Finnie, Childs and Martinello, 2014). In the United States, the postsecondary completion rate is less than 60 percent (NCES, 2016), and even among students who do complete their degrees often do so with minimal grades and questionable human capital acquisition.

Many begin university after having done very well in high school. Figure 1, for example shows the distribution of senior-year high school grades among first year economics students at the University of Toronto. The median acceptance grade average is 86 percent, with a standard deviation of only 3 percentage points. However, student performance diverges widely after only one semester. Figure 1 illustrates this increasing variance, with an especially large lower tail from students failing or near-failing their first-semester courses. Incoming students arrive having achieved stellar grade averages in high school, yet only a small fraction maintain these averages into first year university, and most end up with dramatically lower grades.

Prior research has shown that previous grades are among the best predictors of how well college and university freshman will do, but other non-academic variables also help predict performance. Characteristics such as the Big Five personality traits - conscientiousness, agreeableness, openness to experience, extraversion, neuroticism - and social background sometimes rival cognitive skills in terms of predictive power for a variety of outcomes such as educational attainment, earnings and health (Kautz et al., 2016; Almlund et al., 2011). For instance, meta-analyses show that conscientiousness, a measure of the propensity to stay organized, work hard and persist, is strongly positively associated with educational achievement even after conditioning for cognitive skills (Poropat, 2009). Perseverance towards long-term goals is also correlated with academic outcomes: the trait of grit is positively related with the GPA of students with comparable SAT scores (Duckworth et al., 2007). Work by Mischel et al. 
(1989) and Kirby et al. (2005) suggests that the ability to delay gratification predicts future achievement. Many such personality constructs individually correlate with measures of academic success. However, few data sets allow identifying which variables among all these non-academic measures that have been found to predict college grades best explain the high variance in student performance relative to each other.

In a previous paper (Beattie, Laliberté and Oreopoulos, 2016), we explored what variables best predict unexpected poor or stellar grade performance in first year, after conditioning on high school grade. ${ }^{1}$ To do so, we took advantage of a unique dataset combining a survey of all first year economics students across all three campuses of the University of Toronto (about 6,000 students) and administrative data containing application and performance information. We found that while high school grade remains a strong predictor of subsequent academic performance, several non-academic measures exhibit incremental predictive power. Notably, conscientiousness, expected study hours and purpose-driven motivation were strongly associated with successful and failed transition to postsecondary education.

In this paper, we provide a broader picture of the experiences students go through in first year by following-up with them by the start of second semester. These new pieces of information allow us to explore more closely what sets top and bottom performers apart in terms of their study habits, attitudes, personal experiences, and health. We collect original descriptive data that is not commonly available in order to understand better the wide dispersion in first year performance and its correlates. We look at factors such as mental health, sense of belonging, ambition, and study habits. We also ask students open-ended questions on their biggest struggles in university, what they think they could change to improve, and how the university might help. Using this unique data set, we provide a descriptive analysis of the factors that set Thrivers (students in the top 10 percent of the grade distribution) and Divers (students in the bottom 10 percent) apart in order to understand better the main issues related to the poor performance of first year students, which may, in turn, help suggest opportunities for additional support to reduce poor performance.

The results show that poor time management, lack of study hours and tendencies to cram for exams are the habits most strongly related with poor overall performance. We also find that

\footnotetext{
${ }^{1}$ In this the current paper, we refer to students in the top decile of the end-of-semester grade distribution as Thrivers, and those in the bottom decile, Divers.
} 
top performers are significantly more likely to use the free university resources available to them and to meet with course instructors and tutors. In contrast, Divers are more likely to rely on paid tutors. In terms of mental health, Divers are more likely to report feeling depressed and face personal issues outside school. While a fraction of respondents believes that the university could help by providing more mental health support and resources for non-native English speakers, most Divers do not blame the university for their poor performance and rather suggest that it is up to them to turn things around. However, when asked about what they should be doing better, they often fail to come up with solutions. From this descriptive analysis, we suggest that Divers are facing a vicious circle of poor performance, time and stress management that limit them from identifying efficient solutions to improve their academic performance. We refer to this vicious circle as an "academic trap".

The remainder of the paper proceeds as follows. We describe in Section II the randomized field experiment we implemented to collect an original set of variables on first year students at the University of Toronto. Section III presents the results from the initial survey and the main results from the follow up survey are discussed in Section IV. The results from the text analysis are in Section IV. We conclude in Section V.

\section{Setup and Data Collection}

During the start of the 2016-17 school year, all undergraduate students enrolled in an introduction to economics course at the three campuses of the University of Toronto were required to complete a 'warm-up survey' and 'follow-up survey' as part of their participation grade. Virtually all students (97 percent) completed the warm-up survey within the first three weeks of school - a total of approximately 6,000 students. This represents about a third of all first year students enrolled at this university, and almost $10 \%$ of the entire undergraduate student population. $^{2}$ The overall response rate for the follow-up survey was approximately 83 percent.

\footnotetext{
2 The survey was administered as part of an ongoing field experiment. Students were randomly assigned after completing the survey to different groups, with the control group receiving a onehour personality and non-cognitive skill test, and the treatment groups receiving information on
} 
The lower rate was largely due to students dropping their first year economics course, so that there was no longer a grade incentive to complete. For students who did not drop, the response rate was about the same as the initial survey.

The set of variables that is collected as part of the warm-up survey contains detailed background characteristics such as international student status and parental education, as well as a large set of self-reported measures of study habits and subjective expectations. Linked administrative variables include gender, citizenship, registration status, GPA, all courses taken and grades received at the University of Toronto and, for the majority of students, the high school performance measure used for admission. ${ }^{3}$

The follow-up survey was administered at the start of the second semester (January 2017). The follow-up survey took only about 15 minutes to complete and included questions on subjective well-being, study habits, as well as open ended questions on perceived reasons for poor performance, the biggest challenges faced, and the type of help students could be using that they are not currently getting.

\section{Descriptive Statistics}

Table 1 presents descriptive statistics from the initial survey (Fall 2016), and replicates key results from Beattie, Laliberté and Oreopoulos (2016) using an updated cohort sample and not conditioning on high school grade to provide a more descriptive picture. ${ }^{4}$ In column (1), we report the mean value of the initial survey variables for all entering first year economics students. The next three columns indicate the 25 th, 50th, and 75 th percentiles to provide more information about the distribution of these variables. Column (5) shows the standardized mean difference of these variables between Divers and the full sample (with standard errors in square brackets). For example, self-reported weekly study hours in high school are, on average, 16 percent of a standard deviation lower among Divers than the mean of the full sample. Column (6) shows the

goal-setting, mindset, and/or study advice (see Oreopoulos and Petronijevic, 2016, for more details).

${ }^{3}$ Admission to Canadian universities is primarily determined by academic performance in high schools. Other factors such as student essays and extracurricular activities are rarely included in application materials.

${ }^{4} \mathrm{We}$ do, however, condition on age, campus and cohort, to account for any differences in grading standards. 
corresponding comparison for Thrivers. Finally, the last column indicates the mean difference between Thrivers and Divers - which is close to $40 \%$ of a standard deviation (approximately 4.3 hours per week).

Relative to the full distribution, students who perform poorly tend to study fewer hours both in high school and during their first year at university. They are more likely to study last minute $(0.14$ s.d. above the mean) and less likely to finish what they start $(0.07$ s.d. below the mean). Divers tend to work for pay more hours per week than an average student $(0.16$ s.d. above the mean), they have lower expectations about their grades ( 0.17 s.d. below the mean $)$ and are less likely to aspire to go to grad school (8.5\% below the mean). Unsurprisingly, they also find the transition to college more challenging $(0.11$ s.d. below the mean). In terms of demographics, international students are overrepresented in the bottom 10 percent, but first generation status (i.e. neither of their parents is college-educated) does not predict Diver status.

On the other hand, students among the top decile are less likely to wait at the last minute before starting studying $(0.18$ s.d. below the mean) and more likely to have higher expectations with regards to their grade ( 0.33 s.d. above the mean). Students who excel report studying more hours, on average, in both high school and university. They are also spending less time at a paid job and, to some extent, checking their phone.

\section{Results}

\section{IV.A. Study Habits}

Our main results come from our follow-up survey, which took place at the beginning of the second term (January 2017), and provided an opportunity to have students reflect on their university experiences so far. ${ }^{5}$ Recall that students had to complete both the initial and follow-up survey to receive a 2 percent course participation grade. Virtually every student who had not dropped the course by January completed both surveys.

Table 2 is in the same format as Table 1, comparing mean differences between Thrivers and Divers. In Table 2, however, differences are calculated for self-reported study habits. For

\footnotetext{
${ }^{5}$ We emphasize that the results reported in this study are aimed at mapping important associations with being a Thriver or Diver. They are not meant to imply causality between specific variables.
} 
instance, one of the questions we asked students was, "Last term, when you had no immediate deadlines (say over 2 weeks) about how many hours per week, on average, did you study (outside of class) for all of your courses?". ${ }^{6}$ In the first row we can see that the mean response for the full sample was 10.9 hours per week. Divers studied much less $(0.30$ s.d. below the mean or approximately three hours less than the average student) and Thrivers studied over three hours more than the average student ( 0.33 s.d. above the mean). This implies that on average, Thrivers study close to seven hours per week more than Divers $(\mathrm{p}<0.01)$.

We also asked students how many hours they expect to study in the Winter term when faced with no immediate deadlines. On average, students reported higher intended hours than what they said they did in the Fall, perhaps due to unrealistic expectations (mean of 15 hours per week). The gap in expected hours between low and high performers persists, at 38 percent of a standard deviation. Divers, far from intending to study more than the average in the upcoming semester to make up for their past poor performance, still expect to study significantly less than other students.

In line with these results, Divers more often disagree with the statement that "I manage my time well". The difference in response to this question between Divers and Thrivers is the largest among all the study habits questions we asked (a difference of 69 percent of a standard deviation). In addition, Divers were less likely to write down thoughts and ideas when studying and less likely to remind themselves of their personal goals. They were less likely to meet with their course instructor and free tutors (including TAs), but more likely to meet with an academic advisor and paid tutors. Finally, Divers still report that they found the transition to college much more challenging than the average student. Thrivers, on the other hand, were more likely to report that they manage their time well and learn from their mistakes. They were more likely to remind themselves about their goals and motivations for being in university, and they were also more likely to meet with an instructor or free tutor. Thrivers were less likely to hire a paid tutor.

Overall, the learning habit that appears to most distinguish a Thriver from a Diver is the ability to find sufficient time to study. Meeting with instructors and tutors, learning from past mistakes and thinking about personal goals also sets these types of students apart.

In Figure 2, we look more carefully into the self-reported weekly study hours (excluding hours spent in class) and show the distributions of study hours when there is no immediate

\footnotetext{
${ }^{6}$ The appendix provides the exact wording of the survey questions.
} 
deadline for students with a fall grade above 85 percent and below 65 percent. We find that a large share of low performing students devote five hours of study per week or less. While an important share of top students also spends less than ten hours per week, Figure 2 shows that they are also more likely to study between 15 and 30 hours per week.

\section{IV.B. Mental Health and Overall Experience}

We now turn to the results on mental health, life satisfaction and overall university experience. Table 3 shows that, with the exception of whether students think the university is doing its best to help support them and whether they think their university wants them to be successful, Divers and Thrivers significantly differ on all measures.

Students in the top decile of the grade distribution report to be more satisfied with their life and their university experience. The gap between the average response in life satisfaction between Thrivers and Divers is striking - more than half a standard deviation separates the two groups. In comparison, the average subjective well-being gap between those unemployed and working - is about 0.25 (Helliwell, 2003). Thrivers and Divers also differ markedly by how they respond to feeling stressed and depressed.

Thrivers are more likely to report that it is important for them to do well and feel more confident about their abilities to succeed. Since the beginning of the academic year, they have felt less depressed or stressed. They have a higher grade average for the first term (by construction) and much higher expectations regarding their grades for the incoming semester. High performing students also feel that they belong at their university and, for them, being a student at the University of Toronto is an important part of how they see themselves.

Divers are on average more likely to report a lower life satisfaction and are more likely to have felt depressed over their first semester. Their grades during the Fall semester were more than a full standard deviation below average, and they still expect to obtain relatively low grades in the Winter semester ( 0.65 s.d. below the mean). Students in the bottom of the grade distribution recognize that others understand the material more than themselves and are less confident about their ability to do well, in line with prior results on the important of academic self-efficacy, that is the belief in one's ability to succeed (Richardson et al., 2012). We also find 
that Divers are not as satisfied with their experience at the University of Toronto and are less likely to feel that they belong to their university.

\section{IV.C. Text Analysis of Student Outliers}

In the follow-up survey, students were asked what their biggest challenges have been, what the University of Toronto could do better, and what they plan to do differently. These questions forced students to write a short response in their own words, providing a set of texts to use for a text analysis. In this section, we focus on low performing students and present some of their responses to understand better the main difficulties those students are experiencing.

Figure 3 lists some examples of the biggest challenges reported by the poorest performing students (the worst 25 in the sample). Interestingly, the challenges mentioned varied quite widely. Time management, difficulty to deal with mental health problems and personal issues, transitioning from high school to university and language barriers are examples of challenges divers face. Students also mention their lack of motivation to study and work. When asked what the University of Toronto could be doing more to help, many students reported that they felt the University was doing what it could to help and that the problem rested more on their shoulders. But some students did point out wanting more advice on how to manage their stress and time (see Figure 4). Better coordination on the timing of the submission of writing assignments, especially towards the end of the semester is another example of what they think could be improved to help them succeed better. Divers would like smaller classes and be able to talk more with their course instructors. In Figure 5, we list some examples of what students think they should be doing more to help themselves and succeed better. Managing time, working more and hiring a tutor are examples of what students think they should do better. Although they see that there is a problem and are aware what their biggest challenge is, they do not have a clear solution. We note that some students do not know what they should be doing better.

Finally, we conduct a text analysis of the words used by Thrivers and Divers. The methodology is identical to the text analysis in the initial survey. ${ }^{7}$ After cleaning the text through Microsoft Word's spellcheck, we stem each word to remove grammatical endings such as verb

\footnotetext{
${ }^{7}$ For more details about the methodology and the results from the initial survey, we refer readers to Beattie, Laliberté and Oreopoulos (2016).
} 
tenses and pluralization. We then calculate a Pearson's chi-squared statistic to compare the share of Thrivers (or Divers) who use a given word with the share of the entire sample who used it. Very common words, such as prepositions and articles, are ignored, as are words which are used by fewer than five Thrivers (or Divers). The results of the analysis are a set of words for each question which are used significantly more often by Thrivers, and a second set of words which are used significantly more often by Divers.

The results in Tables 4, 5, and 6 show several patterns. Thrivers discuss workload and time management more often as a common concern. When asked about their biggest challenges, they use words such as "load", "deadline", and "hour", and when asked about what the University of Toronto could do help them more, they mention '"breaks". Thrivers are also more likely to identify these issues as things they plan to work on, as they are more likely to use words such as "focus", and "schedule" when asked what they will try to do differently.

This is consistent with the finding that students who end up being Thrivers are often hard workers, as more hours spent studying allows students entering university to improve on high school performance. It is interesting to note that Thrivers nevertheless seem to find managing study time to be a challenge. This is consistent with the previous finding that conscientiousness is an important factor in predicting success in the high school to university transition, as students who can force themselves to work hard even when they do not want to are more likely to thrive.

Further, Thrivers are more likely to identify issues such as lack of office hours, availability of meeting time with instructors, and study space. According to our survey, they already use these services more than Divers. This suggests that Thrivers are taking advantage of these resources but would like more of them.

There are two major trends among Divers. First, when asked about challenges, Divers are more likely to describe factors which may take time away from studying, using words such as "health" and "job". Our initial analysis identified these factors as predictors of academic problems during the high school to university transition, but it is interesting to note that students appear to be aware of the detrimental effects they have on their grades.

Second, Divers seem to be more lost. When asked about challenges, Divers mentioned used words like "language" and "understand", and when asked what the University of Toronto could do differently, Divers mentioned they needed more information about "details". This 
suggests that students who did poorly transitioning to university found the experience confusing and overwhelming.

\section{Conclusion}

Most students are willing to respond honestly and meaningfully to questions about life satisfaction, well-being, and overall experiences in school. Response rates to these kinds of questions, however, tend to be very low, making it difficult to obtain a representative sample. In this paper, we use a survey that all first-year Economics students $(6,000$ students - 25 percent of all first year students at the University of Toronto) were required to complete for participation grade, and linked responses to administrative data. Doing so provides a rare opportunity to uncover important differences between top and bottom performing students

The sharpest difference between Thrivers and Divers is in terms of how they spend their time. Most Divers report studying for only 5 hours per week when not facing immediate deadlines, and show a large tendency to cram. They also expresses awareness of their time management problem, but nevertheless report expecting to raise study hours the following term only slightly compared to the previous term, leaving them behind. In contrast, Thrivers study on average more than half a standard deviation more than Divers and are much more confident about their time management.

Thrivers are also more likely to meet with their course instructors relative to the average student, whereas Divers tend not to know where to get advice for academic success. When asked about what the University of Toronto could do better, some Divers suggested they would like to have more time to talk with their professors, but most attribute internal reasons behind their struggles.

Our results for the mental health and life satisfaction questions suggest that compared to the average student, Divers are not enjoying their university experience. They are both more likely to report feeling stressed and depressed. They claim that personal problems outside school make their transition to college more challenging. The findings from the text analysis support this result. When asked about their biggest challenges, divers were more likely to describe factors which may take time away from studying such as "friends" and "job". Low performing students report feeling more depressed and some believe that to perform better at school, they 
should "try to be less depressed". This highlights the fact that divers are less likely to know what resources are available to them to obtain mental health support.

The main contrasts we find are consistent with what might be called an "academic trap", in which poor performance is related to difficulty managing time and a tendency to study last minute. This affects and is affected by overall life satisfaction as Divers are more likely to feel depressed and report personal issues as the main challenge to their transition to college. Because students in the bottom of the distribution are also less likely to know where to get academic advice and less likely to meet course instructors and free tutors, they end up lacking guidance for identifying efficient solutions to improve their academic performance. More proactive guidance around time management and quicker response to catch early poor performance are possible interventions worth considering. 


\section{References}

Almlund, Mathilde, Angela Lee Duckworth, James J. Heckman, and Tim D. Kautz. Personality psychology and economics. No. w16822. National Bureau of Economic Research, 2011.

Beattie, Graham, Jean-William P. Laliberté, and Philip Oreopoulos. Thrivers and Divers: Using Non-Academic Measures to Predict College Success and Failure. No. w22629. National Bureau of Economic Research, 2016.

Duckworth, Angela L., Christopher Peterson, Michael D. Matthews, and Dennis R. Kelly. "Grit: perseverance and passion for long-term goals." Journal of personality and social psychology 92, no. 6 (2007): 1087.

Finnie, Ross, Stephen E. Childs, and Felice Martinello. "Postsecondary Student Persistence and Pathways: Evidence From the YITS-A in Canada." Research in Higher Education (2016): 125 .

Helliwell, John F. "How's Life? Combining individual and national variables to explain subjective well-being," Economic Modelling, No. 20 (2003) pp 331-360.

Kautz, Tim, James J. Heckman, Ron Diris, Bas Ter Weel, and Lex Borghans. Fostering and measuring skills: Improving cognitive and non-cognitive skills to promote lifetime success. No. w20749. National Bureau of Economic Research, 2014.

Kirby, Kris N., Gordon C. Winston, and Mariana Santiesteban. "Impatience and grades: Delay-discount rates correlate negatively with college GPA." Learning and individual Differences 15, no. 3 (2005): 213-222.

Mischel, Walter, Yuichi Shoda, and Monica L. Rodriguez. "Delay of gratification in children." Science 244, no. 4907 (1989): 933.

Oreopoulos, Philip, and Uros Petronijevic. "Student coaching: How far can technology go?." Journal of Human Resources (2017): 1216-8439R.

Poropat, Arthur E. "A meta-analysis of the five-factor model of personality and academic performance." Psychological bulletin 135, no. 2 (2009): 322.

Richardson, Michelle, Charles Abraham, and Rod Bond. "Psychological correlates of university students' academic performance: a systematic review and meta-analysis." Psychological bulletin 138, no. 2 (2012): 353 
Figure 1: Density Distributions of Grade Averages in Grade 12 High School and Fall Term First Year College

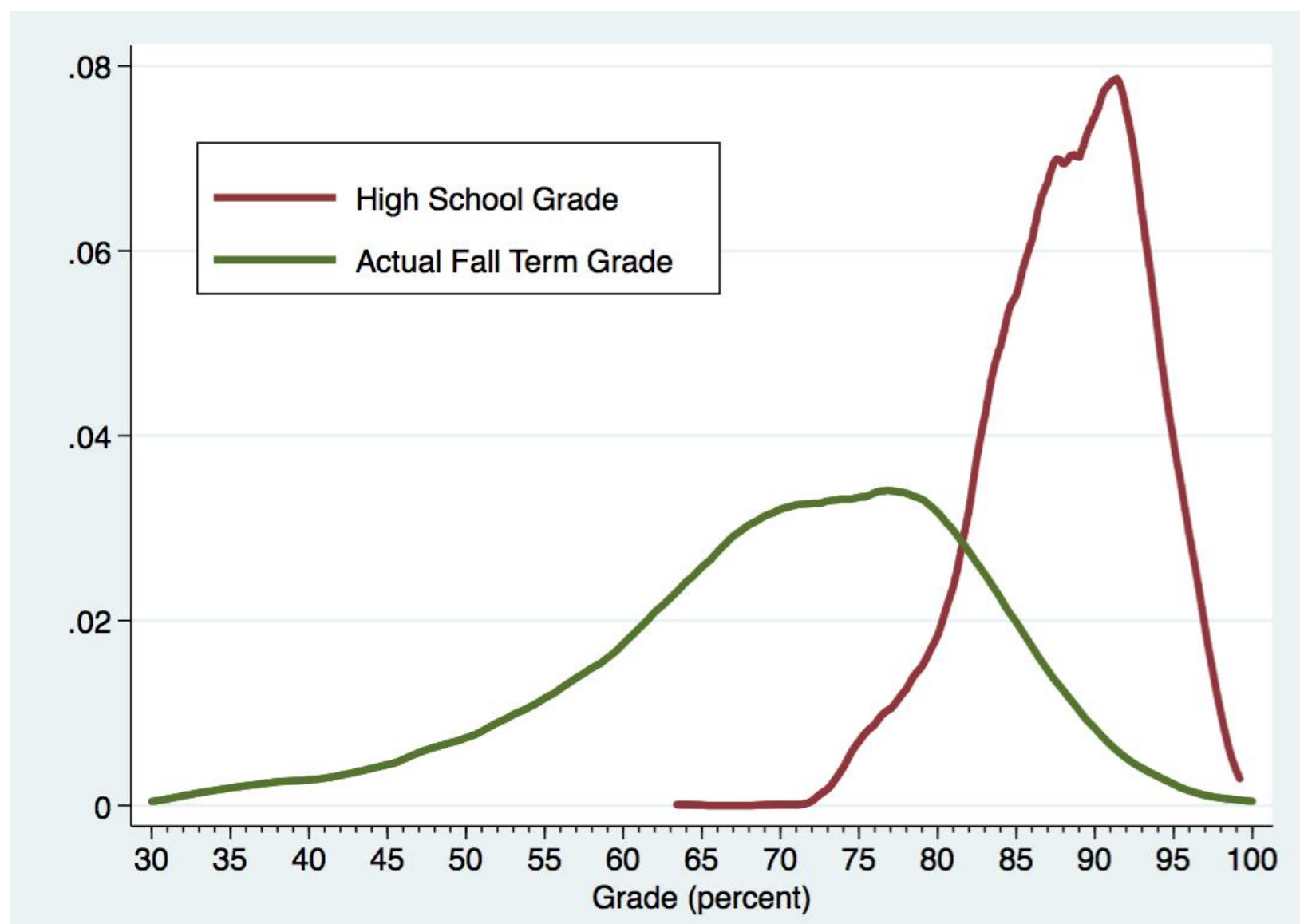

Note: Data for high school and fall term college grades comes from first year economics students at the University of Toronto who participated in the initial survey of the randomized experiment. 
Figure 2: Density Distributions of Weekly Average Study Hours According to Fall Grade

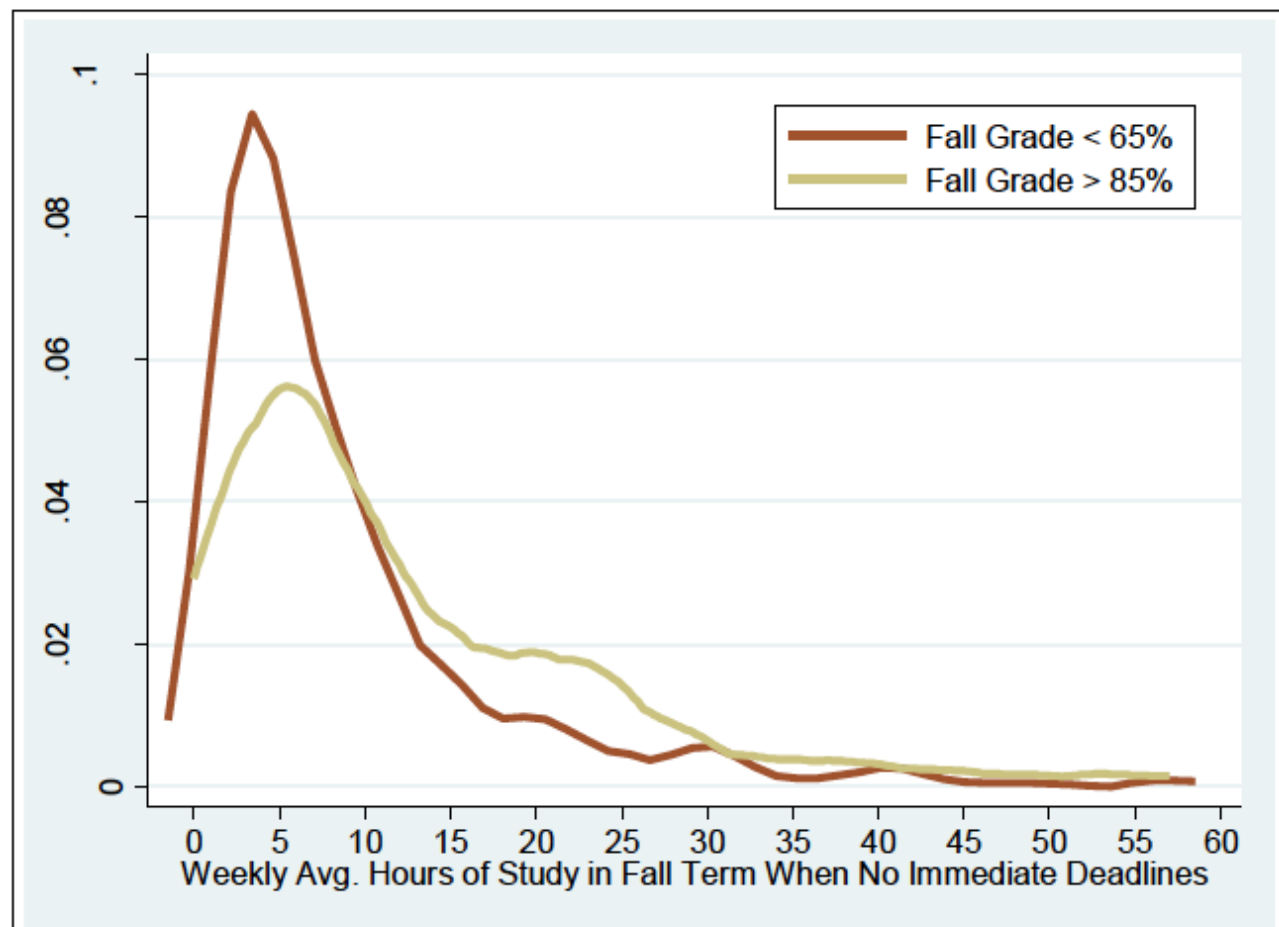

Note: Data for self-reported study hours comes from the follow-up survey of the field experiment. 
Figure 3: Biggest Challenge Among Lowest Performing Students

Sample Phrases

Trying to manage time efficiently

Not being able to focus properly and not getting the mental health treatment as regularly as I would like.

I'm still in the transaction from high school to university and I felt stressed very much. I'm also experiencing lots of stress from my family and relationship.

Adjusting to how different my 3rd world country high school was in comparison to UofT

Having no friends and the fact that no one wants to talk to me in my classes.

Not enough inspiration for me to myself and sometimes I don't know which career should I have.

For me, the biggest challenge is language, because English is not my first language, so I have to take more time to understand what prof. teaches.

Finding motivation to actually sit down and study, in high school I got As without having to do any work or study.

depression has been a huge hindrance in finding motivation to do work/go to class

Sometimes I feel like I am ready for the test or exam. However, after the exam I feel like I don't know anything from my review.

Note: The sample phrases are taken from the responses of divers to the open question "What have been the biggest challenges to your academic success so far?" in the follow-up survey. 
Figure 4: What could the University of Toronto be doing more to help?

\section{Sample Phrases}

I think UofT is doing the best it could, now it's up to me.

I think UofT should create more groups to help those international students in order to help them with their language problems.

Coordinate the timing of assignments and test so that they are better interspersed especially towards the end of the semester.

Give students more advice about time management and how to manage stress.

Make the class size smaller. More time talking to professors.

Note: The sample phrases are taken from the responses of divers to the open question "What could UofT be doing more to help?" in the follow-up survey.

Figure 5: What could YOU be doing more to help?

\begin{tabular}{|l|}
\hline \multicolumn{1}{|c|}{ Sample Phrases } \\
\hline try to be less depressed \\
\hline Focusing a lot more in class and doing all my work. \\
\hline $\begin{array}{l}\text { I am thinking about how I will take a more diverse approach in seeking self-enhancement, } \\
\text { instead of mere academic success. }\end{array}$ \\
\hline I need to have a tutor to help me study. \\
\hline Managing time better \\
\hline No idea to be honest \\
\hline
\end{tabular}

Note: The sample phrases are taken from the responses of divers to the open question "What could you be doing differently?" in the follow-up survey. 


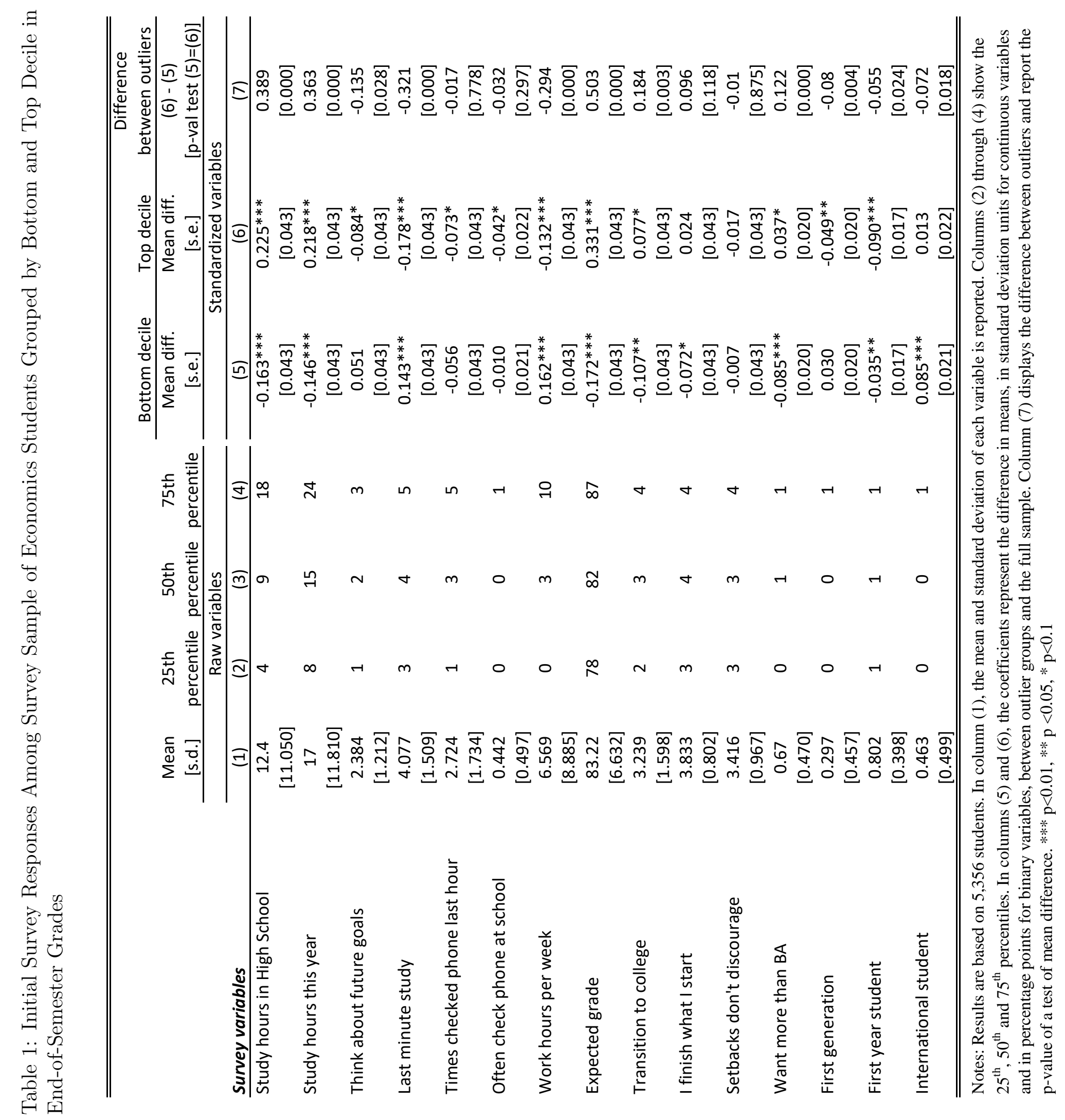




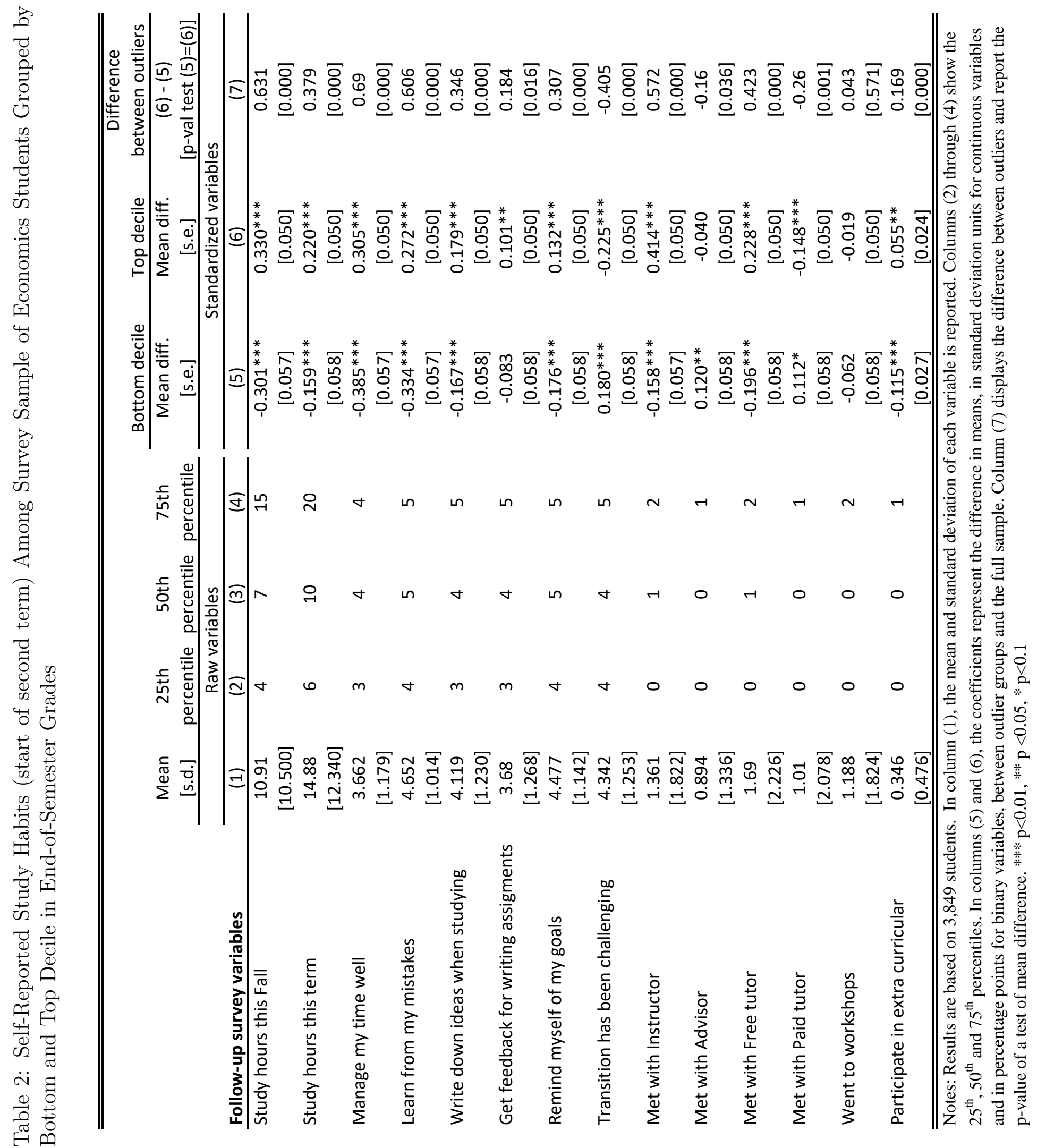




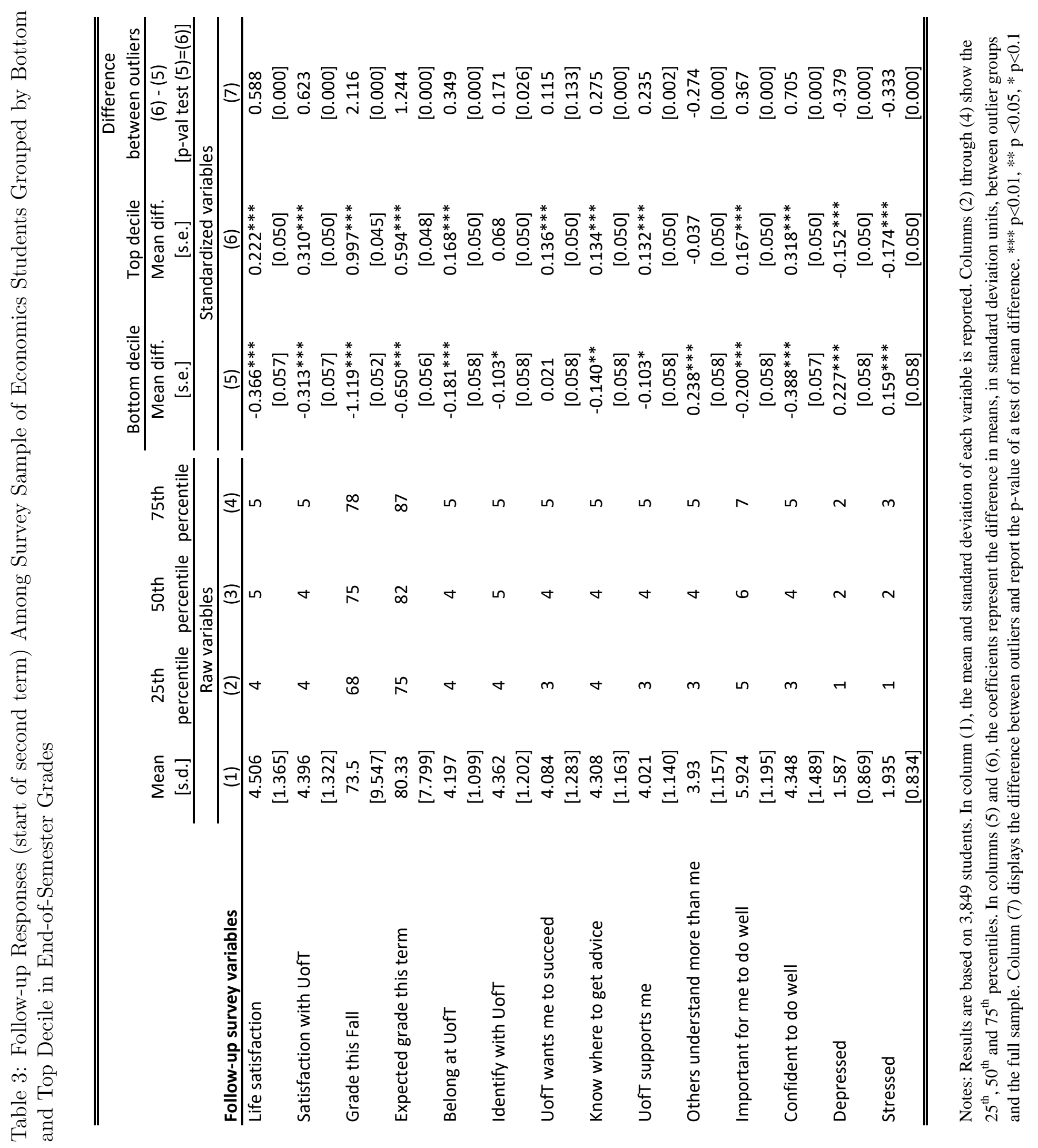


Table 4: Biggest Challenges

What have been the biggest challenges to your academic success so far?

\begin{tabular}{|l|l|l|}
\hline & Top decile words & Bottom decile words \\
\hline $\begin{array}{l}\text { Significant } \\
\text { at } 99 \%\end{array}$ & office & first \\
\hline $\begin{array}{l}\text { Significant } \\
\text { at } 95 \%\end{array}$ & $\begin{array}{l}\text { quiz commute load day deadline } \\
\text { anziety mark }\end{array}$ & job language issue understand \\
\hline $\begin{array}{l}\text { Significant } \\
\text { at } 90 \%\end{array}$ & write speak track science hour & health fail \\
\hline
\end{tabular}

Sample Phrases

\begin{tabular}{l|l} 
office & TA office hours have helped me a lot.
\end{tabular}

Need more office hours

I don't go to office hours or tutorials even though I should.

\begin{tabular}{l|l}
\hline quiz & Keeping calm during quiz (not test).
\end{tabular}

the constant eco100 quizzes are a pain and ruin my sundays.

quiz/exams just keep coming

commute imposing a 2-hour commute each way via public transit

I have a two hour commute to school.

Having to commute to classes

\begin{tabular}{l|l} 
load & learning how to manage the course load has been quite difficult.
\end{tabular}

study load and work off campus

The intense teaching pace as well as heavy work load

\begin{tabular}{l|l}
\hline day & Waking up late causes me to have less time to study throughout the day
\end{tabular}

some days where I would procrastinate and would not get any work done

i spent 5 days to study

deadline Having the motivation to study way before deadlines.

Difficulty in meeting deadlines

getting things done at an appropriate time before deadlines.

\begin{tabular}{l|l} 
anxiety & Coping with with stress and anxiety.
\end{tabular}

I burn out easily and experience anxiety and panic attacks.

The anxiety that I face personally has held me back 


\begin{tabular}{|c|c|}
\hline mark & $\begin{array}{l}\text { Dealing with the pretentious and ambiguous marking scheme. } \\
\text { Ridiculously difficult tests and extremely hard marking } \\
\text { the marking is much more subjective and vague than it should be. }\end{array}$ \\
\hline write & $\begin{array}{l}\text { Language difficulties including writing and speaking. } \\
\text { Theres not much more I can write unfortunately. } \\
\text { Writing assignments and presentations. }\end{array}$ \\
\hline speak & $\begin{array}{l}\text { speaking in a large group of people making me stressed out. } \\
\text { To achieve a higher grade (over } 90 \text { ) generally speaking. } \\
\text { For example, speaking and writing. }\end{array}$ \\
\hline track & $\begin{array}{l}\text { I was able to do enough to stay on track. } \\
\text { stay focused and on track with my studying. } \\
\text { Adjusting my time in able to keep everything on track. }\end{array}$ \\
\hline science & $\begin{array}{l}\text { In my science courses, the amount of material is massive } \\
\text { language and computer science,the boring life in the residence } \\
\text { CSC148 and CSC165 so I can get into the computer science program. }\end{array}$ \\
\hline hour & $\begin{array}{l}\text { Commuting and long hours } \\
\text { I always wish there's } 48 \text { hours a day. } \\
3 \text { hour lectures are boring }\end{array}$ \\
\hline first & $\begin{array}{l}\text { Transitioning from high school to university first year } \\
\text { The teacher doesn't use English since the first class. } \\
\text { I have not had any real challenges since first year }\end{array}$ \\
\hline job & $\begin{array}{l}\text { I have an partime job } \\
\text { Balancing my time between my part time job, my lectures and studying. } \\
\text { I did a very great job at my academic life }\end{array}$ \\
\hline language & $\begin{array}{l}\text { Meeting with new people and making friends due to language barriers. } \\
\text { I don't know being away from family, speaking different languages, } \\
\text { biggest challenge is language, because English is not my first language, }\end{array}$ \\
\hline issue & $\begin{array}{l}\text { I haven't acknowledged the issue until recently } \\
\text { Time management has been a really big issue. } \\
\text { Family issues triggered how I did and depression. }\end{array}$ \\
\hline understand & $\begin{array}{l}\text { I can not understand what prof said in class from time to time } \\
\text { making sure I understand the material well } \\
\text { I don't understand most of the course }\end{array}$ \\
\hline
\end{tabular}




\begin{tabular}{|l|l|}
\hline health & $\begin{array}{l}\text { not getting the mental health treatment as regularly as I would like. } \\
\text { the plague it has been to my life and mental health. } \\
\text { because I faced a lot of problems with my health }\end{array}$ \\
\hline fail & $\begin{array}{l}\text { i just dont understand how i failed it. } \\
\text { I tried to pass the MGM101 but failed, } \\
\text { I have failed to do what I should have done }\end{array}$ \\
\hline
\end{tabular}


Table 5: What could the University of Toronto be doing more to help?

\begin{tabular}{|c|c|c|}
\hline \multicolumn{3}{|c|}{ What could $\mathrm{U}$ of $\mathrm{T}$ be doing more to help? } \\
\hline & Top decile words & Bottom decile words \\
\hline $\begin{array}{l}\text { Significant } \\
\text { at } 99 \%\end{array}$ & lack run & \\
\hline $\begin{array}{l}\text { Significant } \\
\text { at } 95 \%\end{array}$ & meet math space material & friend kind reach \\
\hline $\begin{array}{l}\text { Significant } \\
\text { at } 90 \%\end{array}$ & $\begin{array}{l}\text { hour break advice instructor } \\
\text { course }\end{array}$ & international detail \\
\hline \multicolumn{3}{|c|}{ Sample Phrases } \\
\hline lack & \multicolumn{2}{|c|}{$\begin{array}{l}\text { I was refused by the department because of the lack of prerequisite. } \\
\text { But I feel that there is a lack of TA's, } \\
\text { Nothing really, it's just a lack of motivation. }\end{array}$} \\
\hline run & \multicolumn{2}{|c|}{$\begin{array}{l}\text { school events that run late into the night should be on fridays } \\
\text { instead of running back and forth between family doctors and school, } \\
\text { networking event that runs far into the evening. }\end{array}$} \\
\hline meet & \multicolumn{2}{|c|}{$\begin{array}{l}\text { I rarely get to meet my profs one-on-one to ask for help } \\
\text { clear how to meet with an academic advisor and what that entails. } \\
\text { I sometimes feel not comfortable being at a face-to-face meeting }\end{array}$} \\
\hline math & \multicolumn{2}{|c|}{$\begin{array}{l}\text { Maybe more math aids for higher level courses? } \\
\text { Wednesday is a popular day for a lot of math and csc courses. } \\
\text { The math aid centre is understaffed, }\end{array}$} \\
\hline space & \multicolumn{2}{|c|}{$\begin{array}{l}\text { More comfortable study spaces } \\
\text { UofT could provide more studying spaces, } \\
\text { The UTSC campus could also use more study spaces. }\end{array}$} \\
\hline material & \multicolumn{2}{|c|}{$\begin{array}{l}\text { the difficulty of the material is reasonable. } \\
\text { practice questions and tests that align with the material covered in tests } \\
\text { inconvinent to search and use academic material outside the campus }\end{array}$} \\
\hline hour & \multicolumn{2}{|c|}{$\begin{array}{l}\text { make some more ta office hours } \\
\text { More office hours and less homework. } \\
\text { Try to have less 3-hour lecture blocks }\end{array}$} \\
\hline
\end{tabular}




\begin{tabular}{|c|c|}
\hline break & $\begin{array}{l}\text { fall reading week instead of the short two day fall break. } \\
\text { Give longer winter break. } \\
\text { More break would be better. }\end{array}$ \\
\hline advice & $\begin{array}{l}\text { Give first year students more advice on how to proceed. } \\
\text { mentorship and advice from people who went through the SAME thing } \\
\text { career advice, offer internship }\end{array}$ \\
\hline instructor & $\begin{array}{l}\text { There are only a few instructors, so it is hard to ask questions. } \\
\text { sometimes instructors have to spend more time on erasing the boards. } \\
\text { To make the information about instructors and tutors more accessible on } \\
\text { websites. }\end{array}$ \\
\hline course & $\begin{array}{l}\text { help students with their work and understanding of course materials } \\
\text { Offer more online courses. } \\
\text { Provide more chances for students who take the same course }\end{array}$ \\
\hline friend & $\begin{array}{l}\text { I can study with my friends in the study room. } \\
\text { my friend was kicked out just because he did not pass the ace language. } \\
\text { more event that student can attend to meet new friend }\end{array}$ \\
\hline kind & $\begin{array}{l}\text { have more different kinds of activities } \\
\text { helping students find the right kind of help. } \\
\text { Nothing, it's kind of a personal issue. }\end{array}$ \\
\hline reach & $\begin{array}{l}\text { Have more people to reach out to when i have a problem } \\
\text { Help is out there, all I need to do is to reach for it. } \\
\text { If it could reach out or promote its program more like its health, }\end{array}$ \\
\hline internation & $\begin{array}{l}\text { setting a group for helping international students. } \\
\text { course for international student to teach them how to use all the resources } \\
\text { workshop for international student to learn how to read effectively. }\end{array}$ \\
\hline detail & $\begin{array}{l}\text { explain more details when first years students are choosing courses. } \\
\text { give more details about the test. } \\
\text { need more detailed help since we have few people than other campuses. }\end{array}$ \\
\hline
\end{tabular}


Table 6: What could YOU be doing more to help?

\begin{tabular}{|l|l|l|}
\hline \multicolumn{3}{|l|}{ Thinking of trying differently } \\
\hline & Top decile words & Bottom decile words \\
\hline $\begin{array}{l}\text { Significant } \\
\text { at } 99 \%\end{array}$ & $\begin{array}{l}\text { break mean follow campus place } \\
\text { class person }\end{array}$ & \\
\hline $\begin{array}{l}\text { Significant } \\
\text { at 95\% }\end{array}$ & $\begin{array}{l}\text { day instructor focus question ask } \\
\text { helpful schedule }\end{array}$ & efficient \\
\hline $\begin{array}{l}\text { Significant } \\
\text { at 90\% }\end{array}$ & earlier read term idea \\
\hline break & $\begin{array}{l}\text { I will go to sleep/take a nap/do some yoga/take a walk/take a break. } \\
\text { efficiently take breaks between studying. } \\
\text { I will find myself a volunteer at pharmacy during summer break }\end{array}$ \\
\hline mean & $\begin{array}{l}\text { But by all means the best help will always be financial } \\
\text { what does it mean? } \\
\text { I'm not quite sure what this question means, }\end{array}$ \\
\hline follow & $\begin{array}{l}\text { stay focused/consistent by following the schedule } \\
\text { following a document on how to identify and correct negative thoughts } \\
\text { set clear goals and follow them through }\end{array}$ \\
\hline campus & $\begin{array}{l}\text { Living off campus is really a disadvantage for commuters. } \\
\text { help me excel in this pathetic campus. } \\
\text { be more participated with the campus about everything. }\end{array}$ \\
\hline place & $\begin{array}{l}\text { Studying in the library, or any places without distractions. } \\
\text { Trying to find a place near campus to live. } \\
\text { choosing a place with less distractions }\end{array}$ \\
\hline $\begin{array}{l}\text { studying an hour a day for each class i have a day } \\
\text { Going to class more and take more in depth note, and paying attention. } \\
\text { when I have questions during the class, I will ask professor }\end{array}$ \\
$\begin{array}{l}\text { Put myself out there and talk to people. } \\
\text { After all, we do have a rather large number of people here. } \\
\text { join clubs/groups with people who are interested in similar things as me. }\end{array}$ \\
\hline
\end{tabular}




\begin{tabular}{|c|c|}
\hline day & $\begin{array}{l}\text { Use a planner and try to plan out my day before it starts } \\
\text { I could make a to do list every day, plan my day in advance. } \\
\text { I need to plan for each day and week. }\end{array}$ \\
\hline instructor & $\begin{array}{l}\text { Having more meetings with the course instructors } \\
\text { if I turn to instructors for help } \\
\text { meet with instructors more often }\end{array}$ \\
\hline focus & $\begin{array}{l}\text { I'm focusing on working harder and getting less distracted. } \\
\text { it will help me stay focused and relaxed. } \\
\text { focus more on the necessary ones }\end{array}$ \\
\hline question & $\begin{array}{l}\text { I'm not sure about what this question is asking for. } \\
\text { Don't want to answer this question. Why I cannot leave it blank :( } \\
\text { I don't understand the question English is my second language }\end{array}$ \\
\hline ask & $\begin{array}{l}\text { I will be less hesitant to approach people and to ask them questions. } \\
\text { ask for friends' help. } \\
\text { Study more in quiet spaces and ask for help when I have questions. }\end{array}$ \\
\hline helpful & $\begin{array}{l}\text { trying something differently is always helpful } \\
\text { Of course it would be much more helpful than before. } \\
\text { However, the service is not helpful. }\end{array}$ \\
\hline schedule & $\begin{array}{l}\text { I have visited an academic advisor, and plan on having a good schedule } \\
\text { I can get more time off and have a more stress free schedule/timetable } \\
\text { I am trying to have a more concrete schedule of what to study }\end{array}$ \\
\hline earlier & $\begin{array}{l}\text { Get things done earlier rather than putting them off. } \\
\text { Starting to study earlier than before. } \\
\text { Maybe trying to choose courses earlier. }\end{array}$ \\
\hline read & $\begin{array}{l}\text { Spending weekdays doing course work (e.g., readings) } \\
\text { Do my readings before class. } \\
\text { prioritizing my schedule and focusing on readings when I am reading }\end{array}$ \\
\hline term & $\begin{array}{l}\text { I do need to reschedule in this term, } \\
\text { Studying more and working out once a week this term } \\
\text { seeking help from writing centre instructors this term }\end{array}$ \\
\hline idea & $\begin{array}{l}\text { Have no idea. } \\
\text { i don't have a idea } \\
\text { Sounds great, but I have no specific idea. }\end{array}$ \\
\hline
\end{tabular}




\begin{tabular}{|l|l}
\hline efficient & $\begin{array}{l}\text { improve my efficient of study. } \\
\text { I should work more efficient. } \\
\text { trying to manage my time more efficiently. }\end{array}$ \\
\hline
\end{tabular}

